\title{
Fabrication of High-Voltage Bridge Rectifier Modules for Pulse Power Applications
}

\author{
by Dimeji Ibitayo, Gail Koebke, Damian Urciuoli, and C Wesley Tipton
}




\section{NOTICES}

\section{Disclaimers}

The findings in this report are not to be construed as an official Department of the Army position unless so designated by other authorized documents.

Citation of manufacturer's or trade names does not constitute an official endorsement or approval of the use thereof.

Destroy this report when it is no longer needed. Do not return it to the originator. 


\title{
Army Research Laboratory
}

Adelphi, MD 20783-1138

ARL-MR-0877

September 2014

\section{Fabrication of High-Voltage Bridge Rectifier Modules for Pulse Power Applications}

\author{
Dimeji Ibitayo, Gail Koebke, Damian Urciuoli, and C Wesley Tipton
} Sensors and Electron Devices Directorate, ARL 


\begin{tabular}{|c|c|c|c|c|c|}
\hline \multicolumn{5}{|c|}{ REPORT DOCUMENTATION PAGE } & $\begin{array}{l}\text { Form Approved } \\
\text { OMB No. 0704-0188 }\end{array}$ \\
\hline \multicolumn{6}{|c|}{$\begin{array}{l}\text { Public reporting burden for this collection of information is estimated to average } 1 \text { hour per response, including the time for reviewing instructions, searching existing data sources, gathering and maintaining the } \\
\text { data needed, and completing and reviewing the collection information. Send comments regarding this burden estimate or any other aspect of this collection of information, including suggestions for reducing the } \\
\text { burden, to Department of Defense, Washington Headquarters Services, Directorate for Information Operations and Reports (0704-0188), } 1215 \text { Jefferson Davis Highway, Suite } 1204 \text {, Arlington, VA } 22202-4302 \text {. } \\
\text { Respondents should be aware that notwithstanding any other provision of law, no person shall be subject to any penalty for failing to comply with a collection of information if it does not display a currently } \\
\text { valid OMB control number. } \\
\text { PLEASE DO NOT RETURN YOUR FORM TO THE ABOVE ADDRESS. }\end{array}$} \\
\hline \multicolumn{2}{|c|}{$\begin{array}{l}\text { 1. REPORT DATE }(D D-M M-Y Y Y Y) \\
\text { September } 2014\end{array}$} & \multicolumn{3}{|l|}{ 2. REPORT TYPE } & 3. DATES COVERED (From - To) \\
\hline \multirow{4}{*}{\multicolumn{5}{|c|}{$\begin{array}{l}\text { 4. TITLE AND SUBTITLE } \\
\text { Fabrication of High-Voltage Bridge Rectifier Modules for Pulse Power } \\
\text { Applications }\end{array}$}} & 5a. CONTRACT NUMBER \\
\hline & & & & & \\
\hline & & & & & 5b. GRANT NUMBER \\
\hline & & & & & 5c. PROGRAM ELEMENT NUMBER \\
\hline \multirow{3}{*}{\multicolumn{5}{|c|}{$\begin{array}{l}\text { 6. AUTHOR(S) } \\
\text { Dimeji Ibitayo, Gail Koebke, Damian Urciuoli, and C Wesley Tipton }\end{array}$}} & 5d. PROJECT NUMBER \\
\hline & & & & & 5e. TASK NUMBER \\
\hline & & & & & 5f. WORK UNIT NUMBER \\
\hline \multicolumn{5}{|c|}{$\begin{array}{l}\text { 7. PERFORMING ORGANIZATION NAME(S) AND ADDRESS(ES) } \\
\text { U.S. Army Research Laboratory } \\
\text { ATTN: RDRL-SED-P } \\
\text { 2800 Powder Mill Road } \\
\text { Adelphi, MD 20783-1138 }\end{array}$} & $\begin{array}{l}\text { 8. PERFORMING ORGANIZATION } \\
\text { REPORT NUMBER } \\
\text { ARL-MR-0877 }\end{array}$ \\
\hline \multirow{2}{*}{\multicolumn{5}{|c|}{ 9. SPONSORING/MONITORING AGENCY NAME(S) AND ADDRESS(ES) }} & 10. SPONSOR/MONITOR'S ACRONYM(S) \\
\hline & & & & & $\begin{array}{l}\text { 11. SPONSOR/MONITOR'S REPORT } \\
\text { NUMBER(S) }\end{array}$ \\
\hline \multicolumn{6}{|c|}{ 12. DISTRIBUTION/AVAILABILITY STATEMENT } \\
\hline \multicolumn{6}{|c|}{ 13. SUPPLEMENTARY NOTES } \\
\hline \multicolumn{6}{|l|}{ 14. ABSTRACT } \\
\hline \multicolumn{6}{|c|}{$\begin{array}{l}\text { The advancement of wide bandgap semiconductor materials such as silicon carbide }(\mathrm{SiC}) \text { has made possible devices that } \\
\text { exceed the voltage ratings of conventional packages and modules. Therefore, novel high voltage packages and modules must } \\
\text { be developed to realize the full potential of these technologies. We report on the fabrication of multiple versions of a } 15-\mathrm{kV} \\
\text { bridge rectifier module for pulsed-power applications. }\end{array}$} \\
\hline \multirow{2}{*}{\multicolumn{6}{|c|}{$\begin{array}{l}\text { 15. SUBJECT TERMS } \\
\text { Schottky diodes, solid state rectifiers, semiconductor device packaging, dielectric breakdown }\end{array}$}} \\
\hline & & & & & \\
\hline \multicolumn{3}{|c|}{ 16. SECURITY CLASSIFICATION OF: } & $\begin{array}{l}\text { 17. LIMITATION } \\
\text { OF } \\
\text { ABSTRACT }\end{array}$ & $\begin{array}{l}\text { 18. NUMBER } \\
\text { OF } \\
\text { PAGES }\end{array}$ & $\begin{array}{l}\text { 19a. NAME OF RESPONSIBLE PERSON } \\
\text { Dimeji Ibitayo }\end{array}$ \\
\hline $\begin{array}{l}\text { a. REPORT } \\
\text { Unclassified }\end{array}$ & $\begin{array}{l}\text { b. ABSTRACT } \\
\text { Unclassified }\end{array}$ & $\begin{array}{l}\text { c. } \text { THIS PAGE } \\
\text { Unclassified }\end{array}$ & UU & 24 & $\begin{array}{l}\text { 19b. TELEPHONE NUMBER (Include area code) } \\
\text { 301-394-5514 }\end{array}$ \\
\hline
\end{tabular}




\section{Contents}

List of Figures $\quad$ iv

List of Tables $\quad$ iv

$\begin{array}{ll}\text { 1. Introduction } & 1\end{array}$

2. Module Implementation (Version 1) 1

3. Module Implementation (Version 2) 3

4. Module Implementation (Version 3) 4

5. Conclusions 16

$\begin{array}{ll}\text { List of Symbols, Abbreviations, and Acronyms } & 17\end{array}$

$\begin{array}{ll}\text { Distribution List } & 18\end{array}$ 


\section{List of Figures}

Fig. 1 Exploded view of Version 1, $15 \mathrm{kV}$ full-bridge rectifier module ...................................2

Fig. 2 Completed Version 1, $15 \mathrm{kV}$ full-bridge rectifier module ...........................................2

Fig. 3 Completed Version 2, $15 \mathrm{kV}$ full-bridge rectifier module with CarbAl ${ }^{\mathrm{TM}}$ baseplate.........4

Fig. 4 Exploded view of Version 3, $15 \mathrm{kV}$ full-bridge rectifier module with aluminum

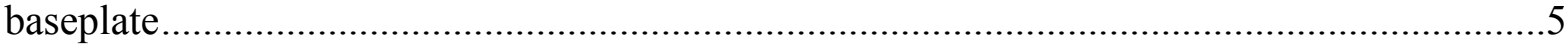

Fig. 5 Solder preform cutter designed and 3D printed at ARL ...........................................6

Fig. 6 Tooling used to assemble module components, including inserts, weight assembly, and weights 7

Fig. 7 Photograph of H.V. rectifier board after die attach and soldering of insulated wires .........8

Fig. 8 Die interconnects made using $0.25 \mathrm{~mm}$ aluminum wire with an ultrasonic bonder ..........9

Fig. 9 Photographs depicting process of sealing of H.V. rectifier board to rectifier case using Dow Corning® 3140 RTV coating ....

Fig. 10 Photographs depicting attachment of aluminum baseplate to module using Bergquist Gap Pad® VO Ultra Soft and size 4-40 machine screws ....

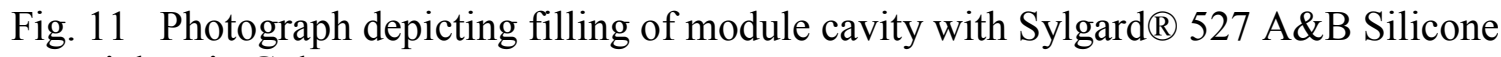
Dielectric Gel

Fig. 12 Photograph depicting sealing of the inner lid using Dow Corning® 3140 RTV coating

Fig. 13 Photograph depicting fill of case cavity with Cotronics Duralco ${ }^{8} 4525 \mathrm{~N}$...................15

Fig. 14 Completed Version 3, $15 \mathrm{kV}$ full-bridge rectifier module with aluminum baseplate ....16

\section{List of Tables}

Table 1 Thermal properties of materials ..........................................................................

Table 2 Version 3 module encapsulants \& adhesives..........................................................15 


\section{Introduction}

Fifteen-kV full-bridge rectifier modules are a custom component developed and fabricated by the US Army Research Laboratory (ARL) in order to demonstrate $15 \mathrm{kV}, 3-\mathrm{A}$, and 6-A silicon carbide (SiC) junction barrier Schottky rectifier modules in application circuits. Such high voltage, high-speed rectifiers help reduce power conversion volume while increasing efficiency. This development also serves to identify challenges associated with high voltage semiconductor packaging. The SiC junction-barrier Schottky (JBS) diodes used in the module were state-of-theart devices developed and fabricated by CREE Inc. under the Defense Advanced Research Projects Agency's Wide Bandgap Semiconductor Technology Initiative. The 3-A rated die are $8 \mathrm{~mm} \times 8 \mathrm{~mm}$ in total area, and the $6-\mathrm{A}$ rated die are $10 \mathrm{~mm} \times 10 \mathrm{~mm}$.

\section{Module Implementation (Version 1)}

Three versions of the $15 \mathrm{kV}$ bridge rectifier modules were fabricated at ARL for various applications. A total of 12 modules have been fabricated to-date, using a multi-step packaging and assembly process. Version 1 (V1) was developed for a 40-kV converter and used the 3-A $\mathrm{SiC}$ JBS diodes mounted on a Curamik Electronics aluminum nitride (AlN) direct bond copper (DBC) substrate material $(0.3 \mathrm{~mm} \mathrm{Cu} / 0.6 \mathrm{~mm} \mathrm{AlN} / 0.3 \mathrm{~mm} \mathrm{Cu})$. For all versions of the module, the DBC substrate was patterned to meet electrostatic simulation criteria and to accommodate devices, bond wires, and terminals on the top side. An exploded view of V1 is shown in Fig. 1, and a photograph of a completed module is shown in Fig. 2. As shown in Fig. 1, a pocket was cut into the top face of the copper heat sink. The bottom-side copper on the substrate was also removed within the pocket region but remained outside the pocket region to allow for soldering of the substrate to the heat sink. A set of holes was drilled through the heat sink to allow the resulting pocket to be partially filled with encapsulant for high voltage operation following solder bonding. 


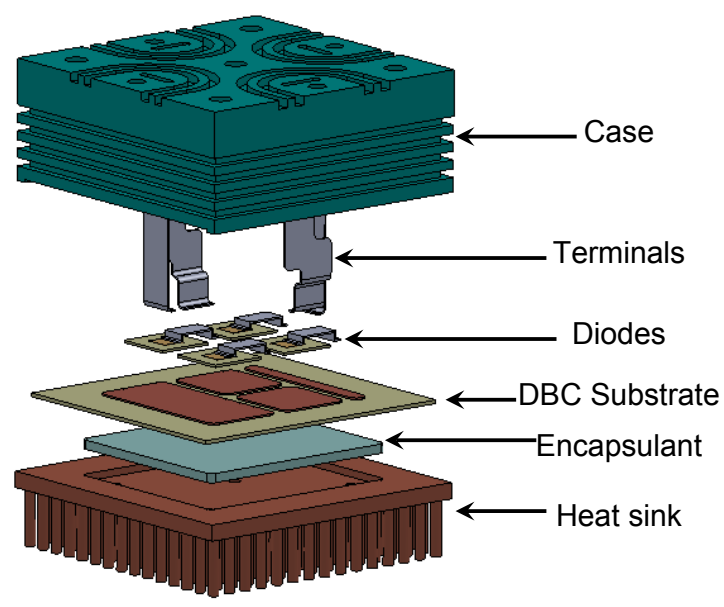

Fig. 1 Exploded view of Version 1, $15 \mathrm{kV}$ full-bridge rectifier module

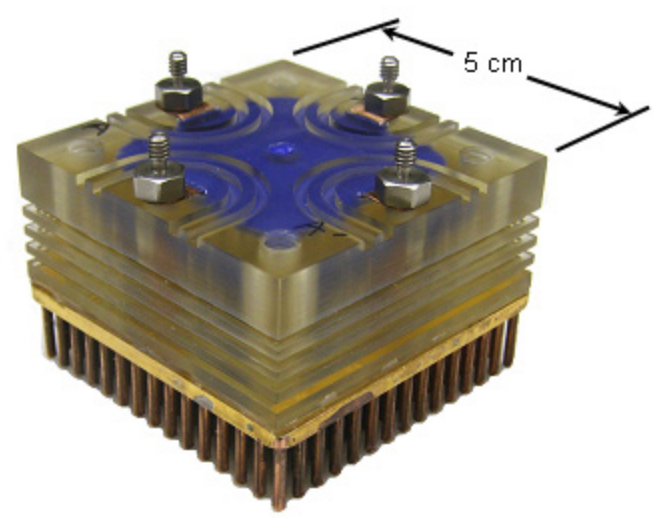

Fig. 2 Completed Version 1, $15 \mathrm{kV}$ full-bridge rectifier module

Solder bonding at the diode-to-substrate and substrate-to-heat sink interfaces was performed using a single-step process in a vacuum reflow oven to achieve low voiding within the solder. A $\mathrm{Sn}-\mathrm{Ag}-\mathrm{Cu}$ alloy solder was used on both interfaces, and the process temperature profile was tailored to reduce mechanical stress in the final assembly. However, cracks were formed as a result of thermomechanical stresses within the DBC substrate after the soldering process. After the die, substrate, and heat sink were bonded, the die interconnects were made using $0.25 \mathrm{~mm}$ aluminum bond wires. Finally, 4 copper terminals were attached to the substrate using a $\mathrm{Sn}-\mathrm{Pb}$ alloy solder.

The plastic case was constructed from Ultem PEI having a maximum working temperature of $168^{\circ} \mathrm{C}$. In addition to its high temperature rating, this material has a voltage breakdown rating in excess of $20 \mathrm{MV} / \mathrm{m}$ and low moisture absorption. The height of the case and terminal locations was specified to provide sufficient separation of all conductors, including the heat sink, to prevent voltage breakdown in air. Grooves were machined into the outside surfaces of the case to mitigate voltage creep. The case was attached to the substrate assembly using room-temperature 
vulcanizing (RTV) silicone. Because the module was designed to have the heat sink at a floating potential, the case has 4 threaded holes for module mounting. Similar to the heat sink, a hole was placed in the top of the case to allow approximately three-quarters of the die cavity to be filled with an encapsulant, Dow Corning Sylgard ${ }^{\circledR} 527$. This product was chosen because encapsulants with high curing temperatures entrapped many voids. The remainder of the cavity was filled with Cotronics Duralco® ${ }^{\circledR} 537 \mathrm{~N}$ epoxy to bind the terminals. The encapsulant was cured under a partial vacuum. Both the encapsulant and epoxy were cured at $27^{\circ} \mathrm{C}$.

\section{Module Implementation (Version 2)}

The Version 2 module (V2) was developed for the same application as V1 in order to address thermomechanical concerns that arose during the assembly of V1. In the case of V2, a CarbAlTM baseplate was used in place of the copper pin fin heat sink. CarbAl ${ }^{\mathrm{TM}}$ is a carbon-based nanocomposite comprised of a $20 \%$ dispersed aluminum in $80 \%$ carbon. The coefficient of thermal expansion (CTE) of CarbAlTM, as shown in Table 1, is significantly lower than that of copper and is a closer match to the AIN DBC substrate and silicon carbide. The cracking of the DBC substrate that occurred in the construction of V1 was not experienced with the change from copper to $\mathrm{CarbAl}^{\mathrm{TM}}$. CarbAl ${ }^{\mathrm{TM}}$ also possesses a high thermal conductivity.

Table 1 Thermal properties of materials

\begin{tabular}{|c|c|c|}
\hline Material & $\begin{array}{c}\text { Thermal conductivity } \\
(\mathbf{W} / \mathbf{m} \cdot \mathbf{K})\end{array}$ & $\begin{array}{c}\text { Coefficient of thermal expansion } \\
\left(\mathbf{p p m} /{ }^{\circ} \mathbf{C}\right)\end{array}$ \\
\hline $\mathrm{SiC}$ & 120 & $3.5-5.0$ \\
\hline $\mathrm{AlN}$ & 185 & 4.5 \\
\hline Copper & 385 & 16.6 \\
\hline CarbAl-NTM & $350-400^{*}$ & $6.60-7.44$ \\
\hline $\mathrm{k}_{\mathrm{z}}$, compared to $\mathrm{k}_{\mathrm{x}, \mathrm{y}}=150-200 \mathrm{~W} / \mathrm{m} \cdot \mathrm{K}$ &
\end{tabular}

A photograph of the completed V2 module is shown in Fig. 3. The DBC substrate was soldered directly to an electroless nickel immersion gold (ENIG) plated CarbAl ${ }^{\mathrm{TM}}$ baseplate. Cotronics Duralco ${ }^{\circledR} 4525 \mathrm{~N}$ epoxy was used for binding the terminals due to its lower moisture absorption and higher strength. All of the other materials and processing were identical to what was used in V1. 


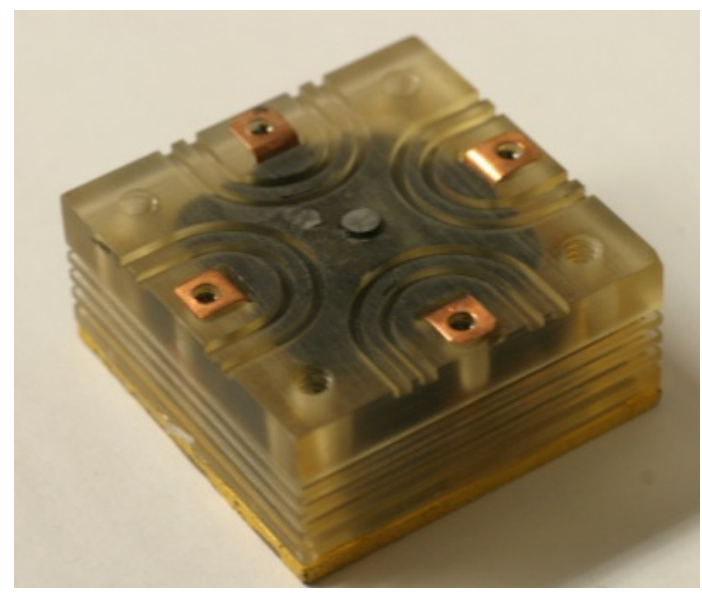

Fig. 3 Completed Version 2, $15 \mathrm{kV}$ full-bridge rectifier module with $\mathrm{CarbAl}^{\mathrm{TM}}$ baseplate

\section{Module Implementation (Version 3)}

ARL provided the design and Stellar Industries Corporation was responsible for photopatterning, copper etching, and electroless nickel immersion gold (ENIG) plating on a Curamik Electronics DBC substrate material $(0.3 \mathrm{~mm} \mathrm{Cu} / 1.0 \mathrm{~mm}$ AlN/0.3 $\mathrm{mm} \mathrm{Cu})$. The availability of the thicker ceramic layer allowed for $15 \mathrm{kV}$ operation without the requirement of the dielectric pocket used in the previous 2 versions. Additionally, aluminum was used as the base-plate material, and Gap Pad® VO Ultra Soft was used for heat transfer between the substrate and baseplate in order to dampen vibration. Size 4-40 screws were also used in order to secure the case to the base-plate. Noryl PPO plastic was used instead of Ultem as the case material due to its opacity and reduced cost. Although both plastics have suitable electrical, mechanical, and thermal properties, they are susceptible to stress-cracking in the presence of some common organic compounds such as acetone, gasoline, and kerosene. Both Ultem and Noryl also exhibited stress-cracking when exposed to Loctite 242 Threadlocker ${ }^{\circledR}$, which was, therefore, eliminated from the module mounting process. As before, the substrate was designed to meet electrostatic simulation criteria and to accommodate devices, bond wires, and wire terminals on the top side. The use of wire terminals extending from the package simplified module fabrication, while effectively eliminating voltage creep at the module case. To reduce strain normal to the substrate, an inner lid was sealed into the case forming an air pocket above the encapsulant to accommodate its thermal expansion. Cotronics Duralco ${ }^{\circledR} 4525 \mathrm{~N}$ epoxy was used to fill the remainder of the open cavity and to bind the wire terminals. An exploded view of the version 3 module is depicted in Fig. 4. 


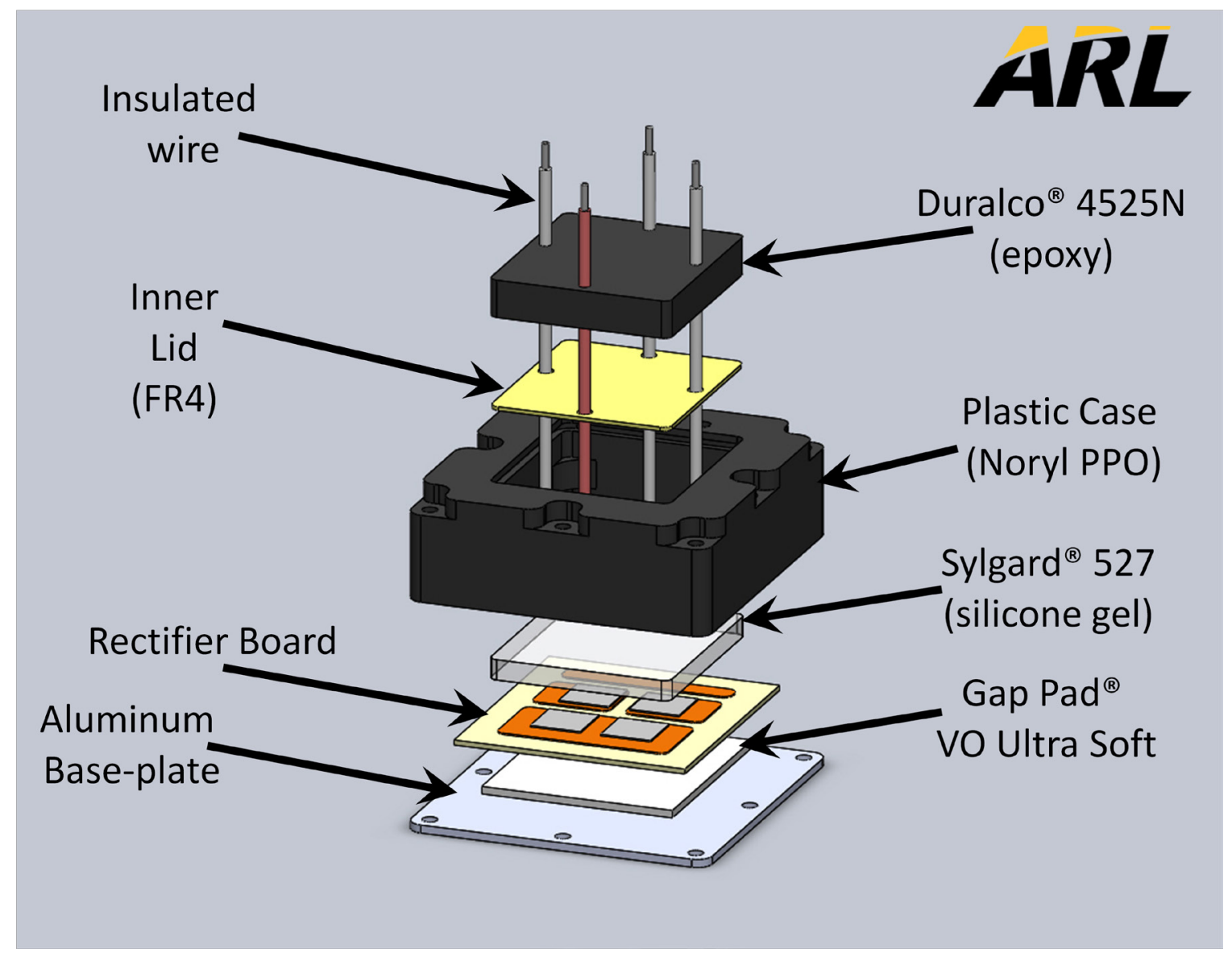

Fig. 4 Exploded view of Version 3, $15 \mathrm{kV}$ full-bridge rectifier module with aluminum baseplate

The following is a step-by-step procedure for the assembly of the V3 module:

\section{Step 1: Moisture bake out of module components}

- Place H.V. rectifier board, inner lid, case, and insulated wire in oven

○ Subject components to a $24-\mathrm{h}$ bake-out at $100{ }^{\circ} \mathrm{C}$ to remove moisture

\section{Step 2: Cutting and cleaning diodes and gold-tin (80Au20Sn) solder preforms}

○ Cut AuSn preforms (0.002 in. thick) for each diode to $\sim 90 \%$ of the device size using preform cutter as in Fig. 5

- Soak preforms in acetone and ultrasonic clean for $1 \mathrm{~min}$

- Rinse each preform with isopropyl alcohol (IPA) and blow dry with nitrogen

- Clean diodes with IPA, ensuring cleanliness of backsides

- Rinse with IPA and blow dry with nitrogen 


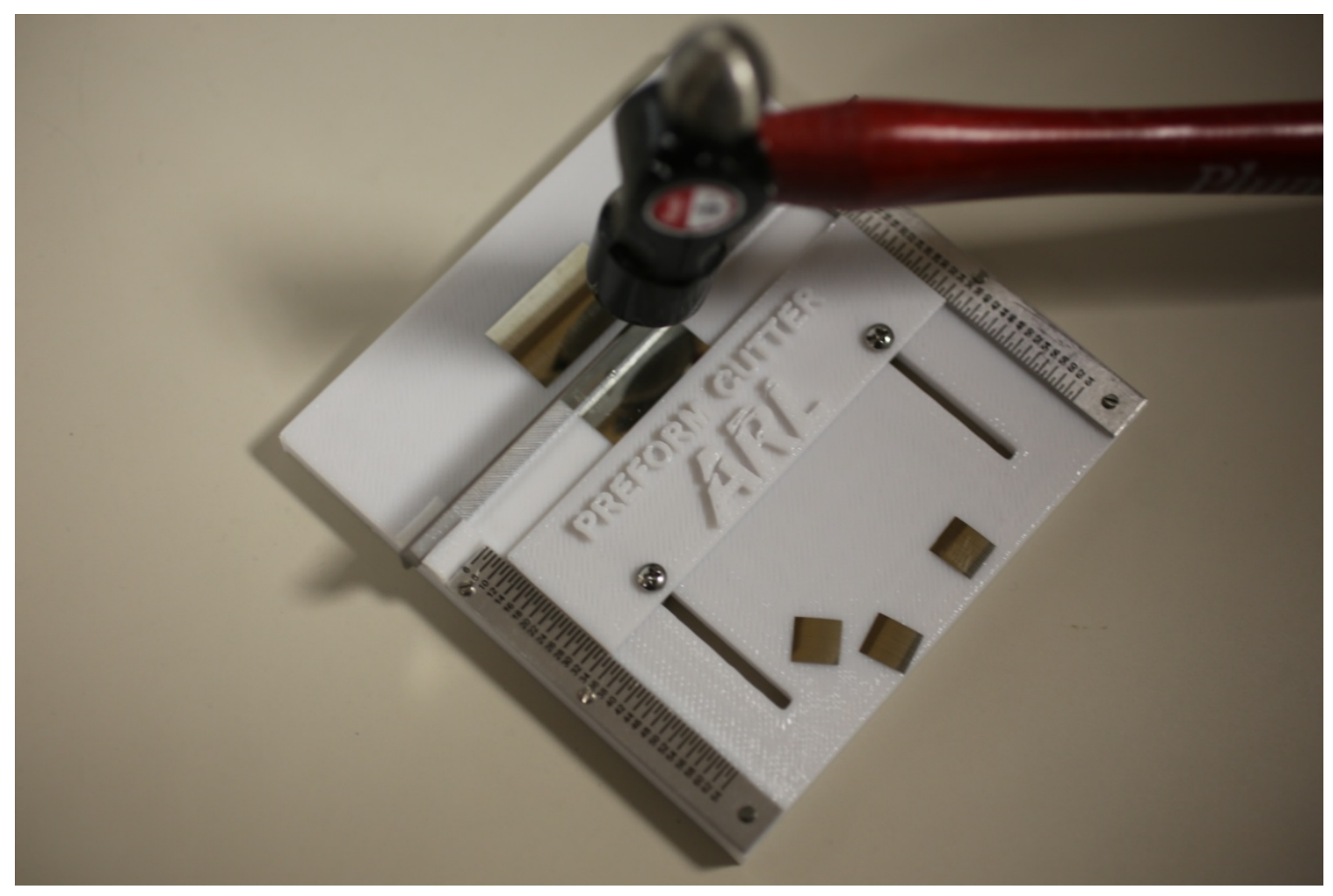

Fig. 5 Solder preform cutter designed and 3D printed at ARL

\section{Step 3: Bonding of SiC JBS diodes to H.V. rectifier board in vacuum-pressure furnace}

- Use the graphite tooling to assemble all the module components as in Fig. 6

- Place the DBC substrate on the tooling base plate

- Place the thin graphite template on top of the DBC

- Place the AuSn preforms on the DBC in the windows of the template

- Place the JBS diodes on top of the preforms

- Place the top portion of the tooling over the tooling base plate

- Carefully lower the weights through the holes in the tooling

- Place the tooling assembly in the vacuum furnace and run AuSn reflow profile $\left(\mathrm{T}_{\text {peak }}=\right.$ $\left.310{ }^{\circ} \mathrm{C} ; \mathrm{t}_{\mathrm{AL}}=1: 10 \mathrm{sec}\right)$ 


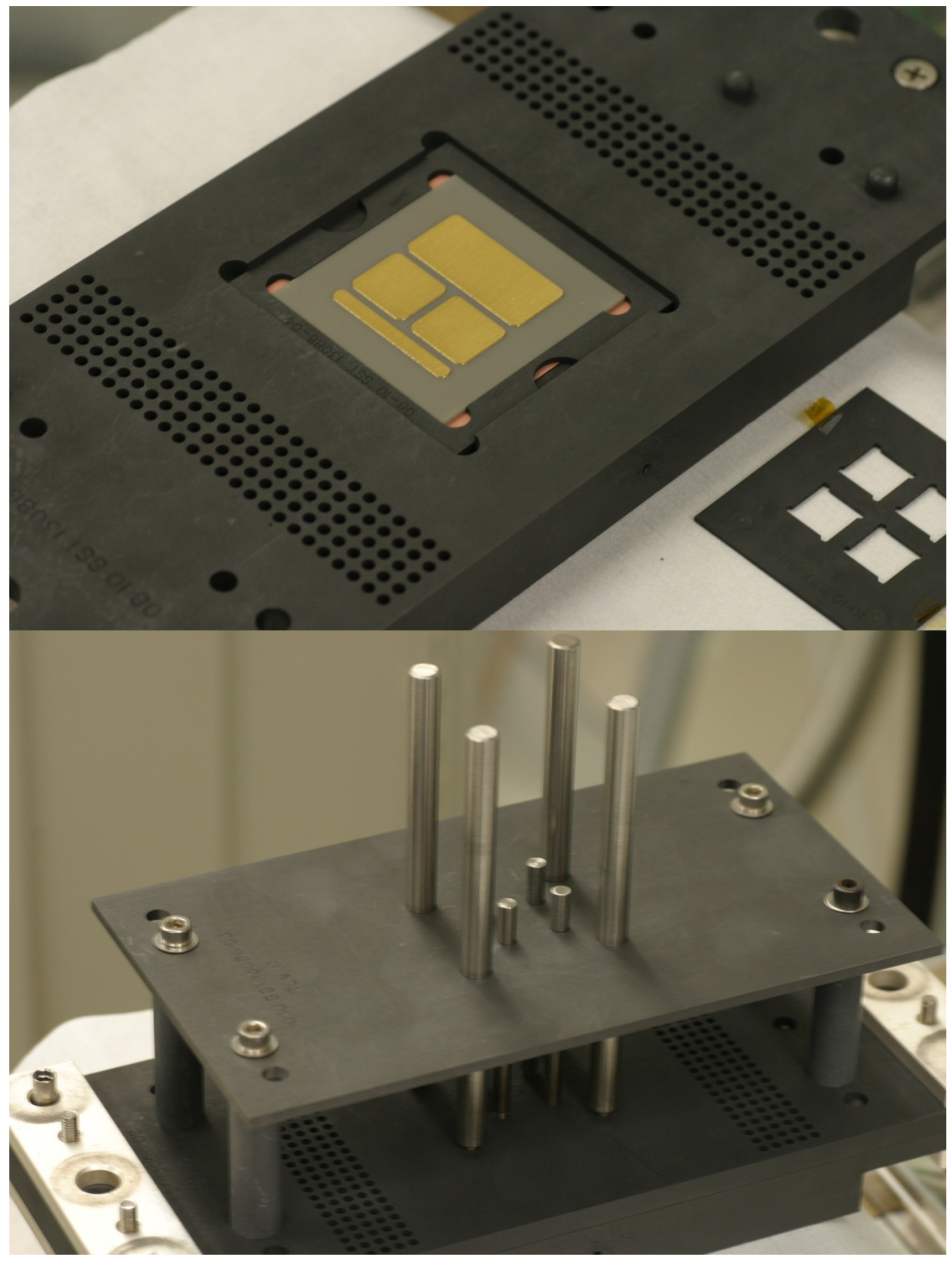

Fig. 6 Tooling used to assemble module components, including inserts, weight assembly, and weights 
Step 4: Soldering insulated wires onto the DBC substrate using tin-lead (63Sn37Pb) RMA solder

- Use H.V. rectifier inner lid as a locator guide to solder wire leads onto DBC pads

- Solder a $12 \mathrm{in.} \mathrm{long} \mathrm{red} \mathrm{wire} \mathrm{to} \mathrm{DC} \mathrm{positive} \mathrm{pad,} \mathrm{and} 12 \mathrm{in}$. white wire to the other 3 locations as shown in Fig. 7

- Thoroughly clean all flux residue from the wire, DBC, and devices

- Ensure that wire insulation will extend below the top surface of the encapsulant when added

Fig. 7 Photograph of H.V. rectifier board after die attach and soldering of insulated wires

\section{Step 5: Wire bonding devices to DBC}

- Wire bonds were made using Orthodyne ${ }^{\circledR}$ Model 20 Ultrasonic bonder

○ Aluminum wire $(0.25 \mathrm{~mm})$ used for all wire bonds as seen in Fig. 8

- Three wire bonds were placed on each device 


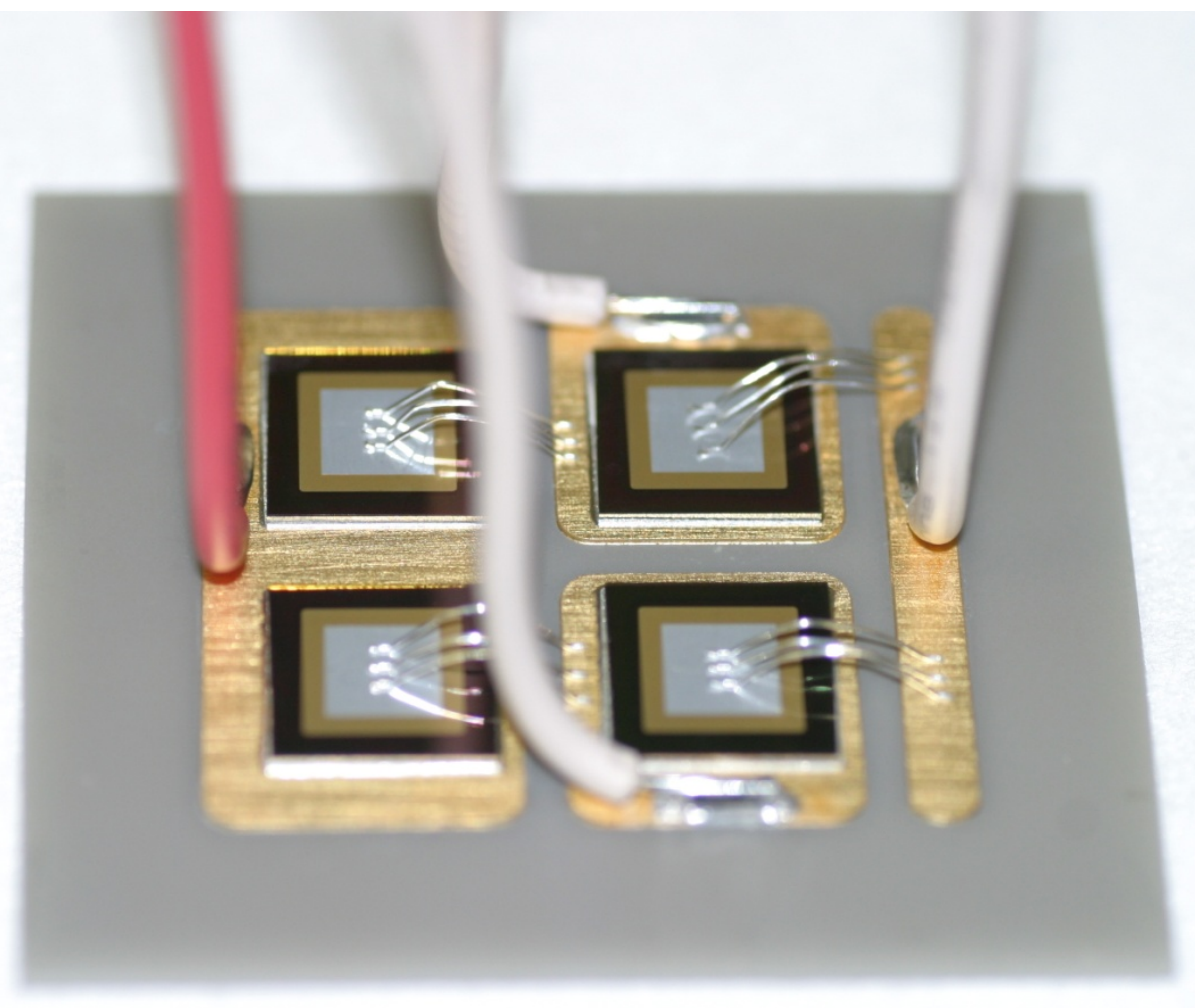

Fig. 8 Die interconnects made using $0.25 \mathrm{~mm}$ aluminum wire with an ultrasonic bonder

\section{Step 6: Sealing H.V. rectifier board to H.V. rectifier case}

- Apply thin coat of Dow Corning ${ }^{\circledR} 3140$ RTV and press board firmly to case

- Place module upside down with weight on the backside of the DBC as shown in Fig. 9

- Allow $24 \mathrm{~h}$ for RTV to cure at $27^{\circ} \mathrm{C}$ 


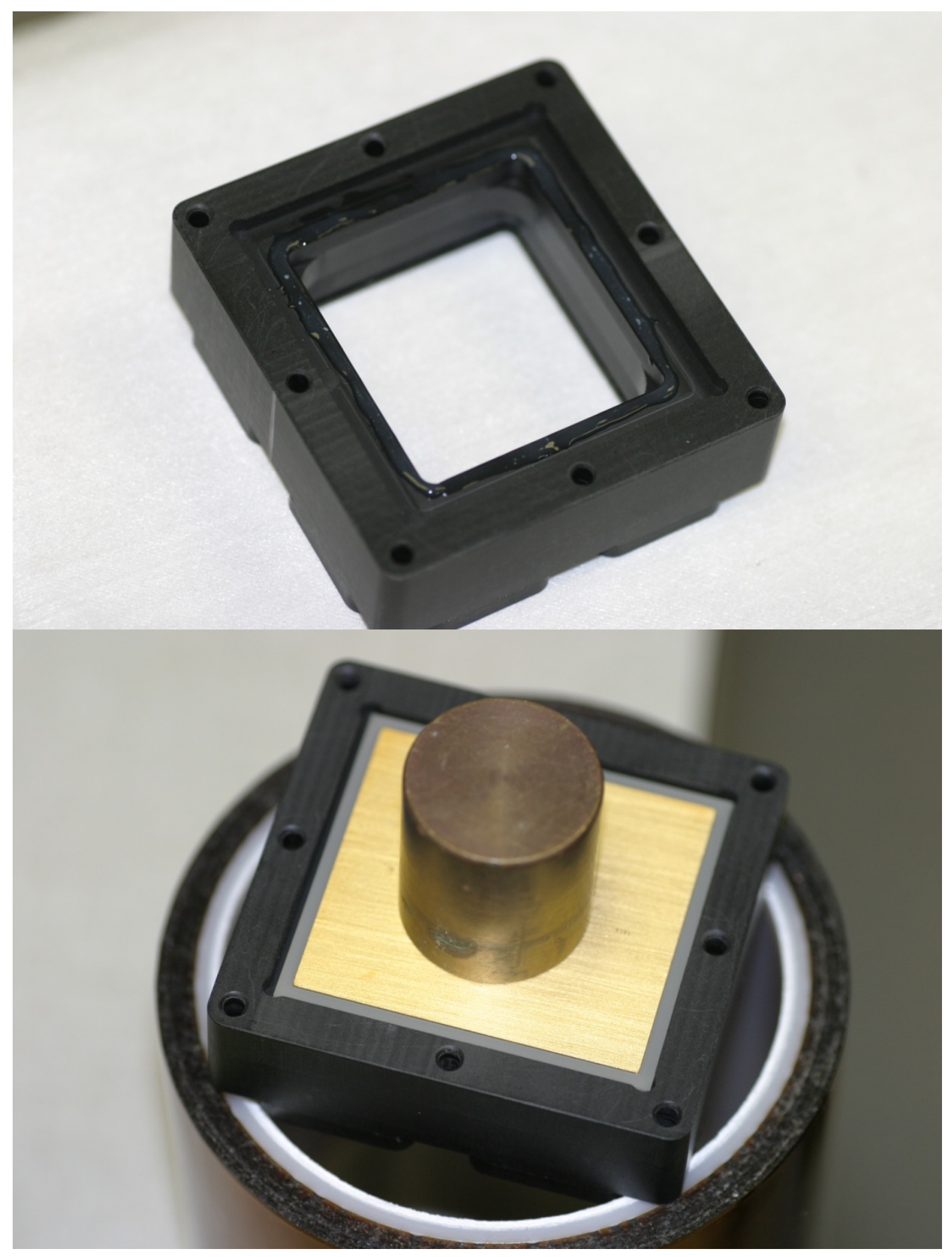

Fig. 9 Photographs depicting process of sealing of H.V. rectifier board to rectifier case using Dow Corning 3140 RTV coating 


\section{Step 7: Attach aluminum baseplate to module}

○ Cut $1.5 \mathrm{~mm}$ Bergquist Gap Pad ${ }^{\circledR}$ VO Ultra Soft using template $(38 \mathrm{~mm} \times 42 \mathrm{~mm})$ and remove blue film

- Apply the gap pad to the exposed backside of the DBC ensuring that it is centered as in Fig. 10

- Fasten aluminum baseplate to the case using size 4-40 machine screws, nuts, and washers

- Securely tighten the screws to compress the gap pad so there is no space between the aluminum plate and the case 

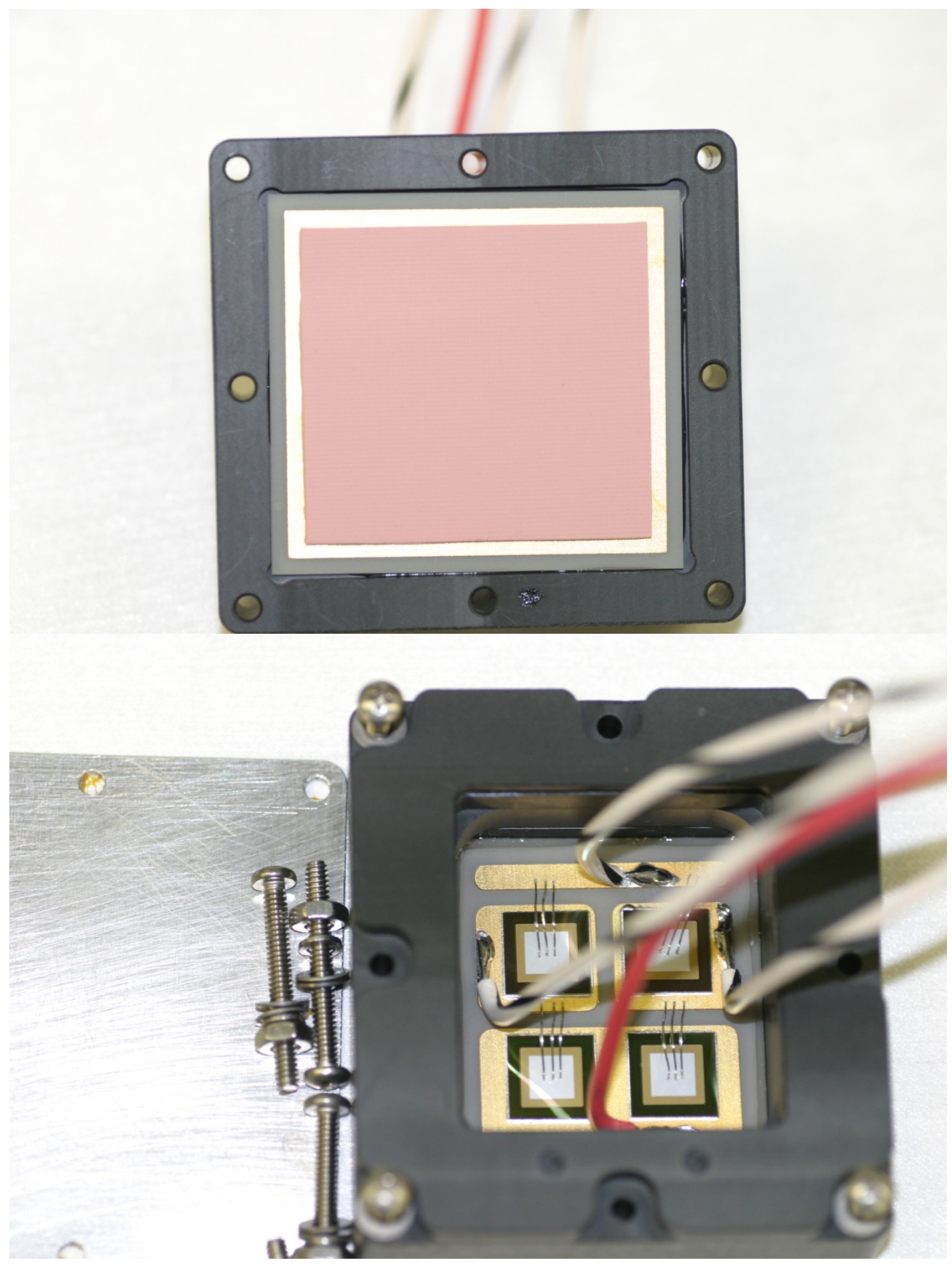

Fig. 10 Photographs depicting attachment of aluminum baseplate to module using Bergquist Gap Pad ${ }^{\circledR}$ VO Ultra Soft and size 4-40 machine screws 


\section{Step 8: Encapsulate die cavity using Sylgard ${ }^{\circledR} 527$ A\&B Silicone Dielectric Gel}

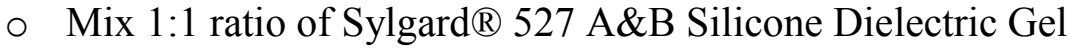

- Degas under vacuum to ensure a void-free protective layer

- Dispense the gel into the die cavity (see Fig. 11) below top of corner webs in case

- Inspect for void entrapment

- Allow $24 \mathrm{~h}$ for gel to cure at $27{ }^{\circ} \mathrm{C}$

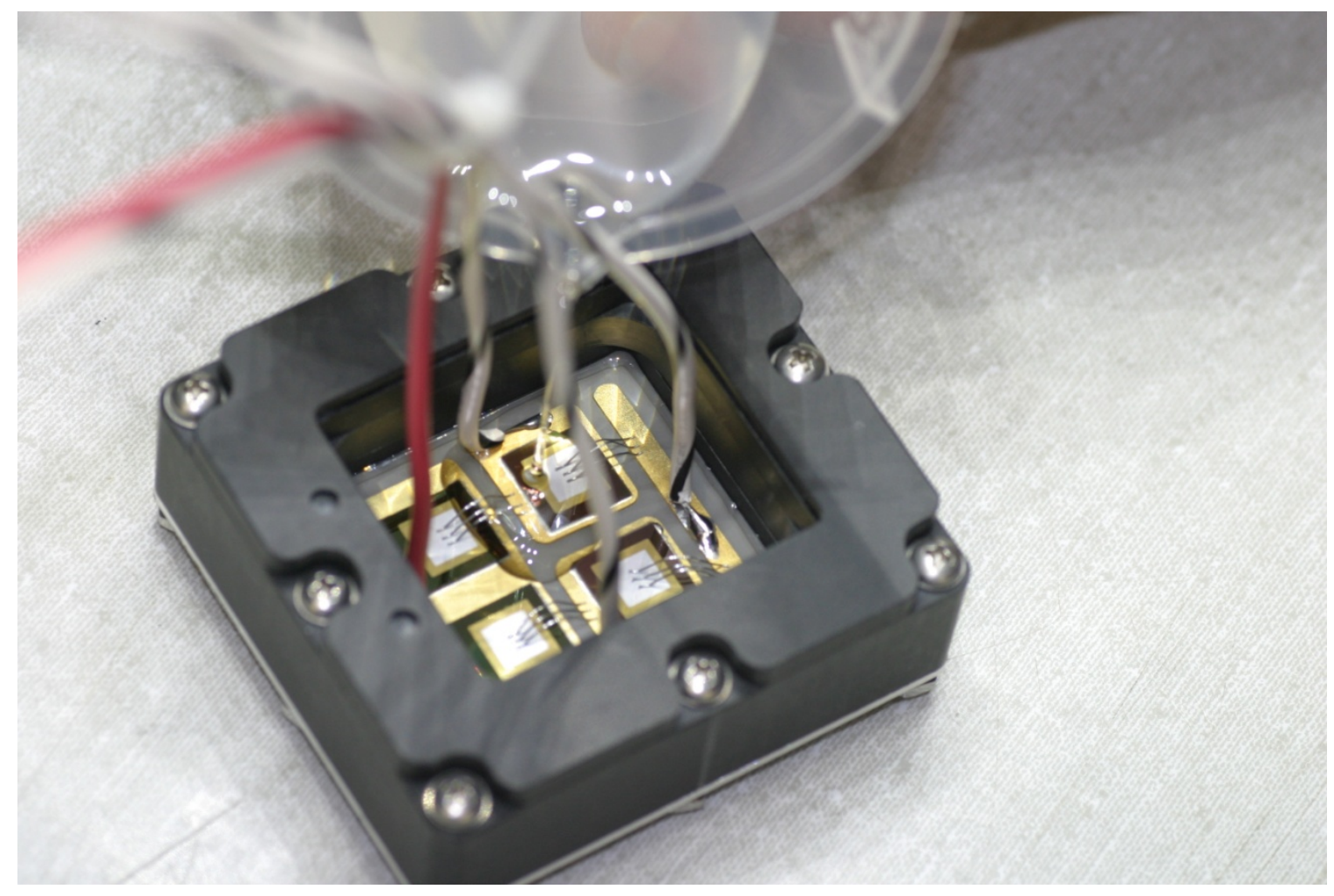

Fig. 11 Photograph depicting filling of module cavity with Sylgard® 527 A\&B Silicone Dielectric Gel

\section{Step 9: Seal inner lid to case using Dow Corning® 3140 RTV Coating}

- Slide inner lid onto wires and seat on top of case corner webs

- Seal inner lid to case and around wires for a liquid tight seal using RTV coating as seen in Fig. 12

- Avoid applying excessive RTV on the inner side walls of the case and wires where they come through the lid

- Allow $24 \mathrm{~h}$ for RTV to cure at $27^{\circ} \mathrm{C}$ 


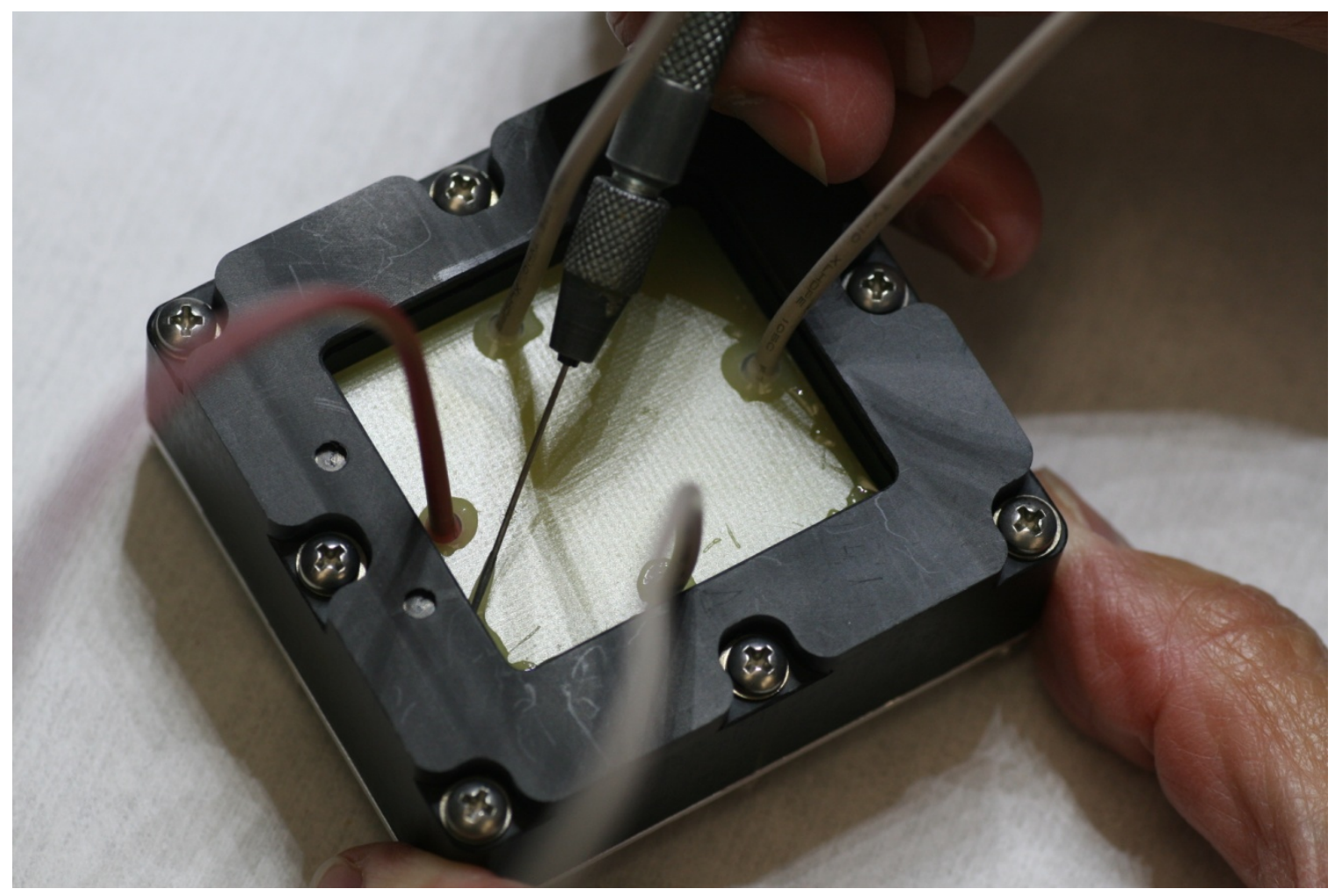

Fig. 12 Photograph depicting sealing of the inner lid using Dow Corning ${ }^{\circledR} 3140$ RTV coating

Step 10: Seal top of case with Cotronics Duralco ${ }^{\circledR} 4525 N$ to provide strain relief to wires

- Fill case cavity with Duralco ${ }^{\circledR} 4525 \mathrm{~N}$ epoxy as in Fig. 13, ensuring the epoxy runs into upper side wall groove

- Allow $24 \mathrm{~h}$ for epoxy to cure at $27^{\circ} \mathrm{C}$ 


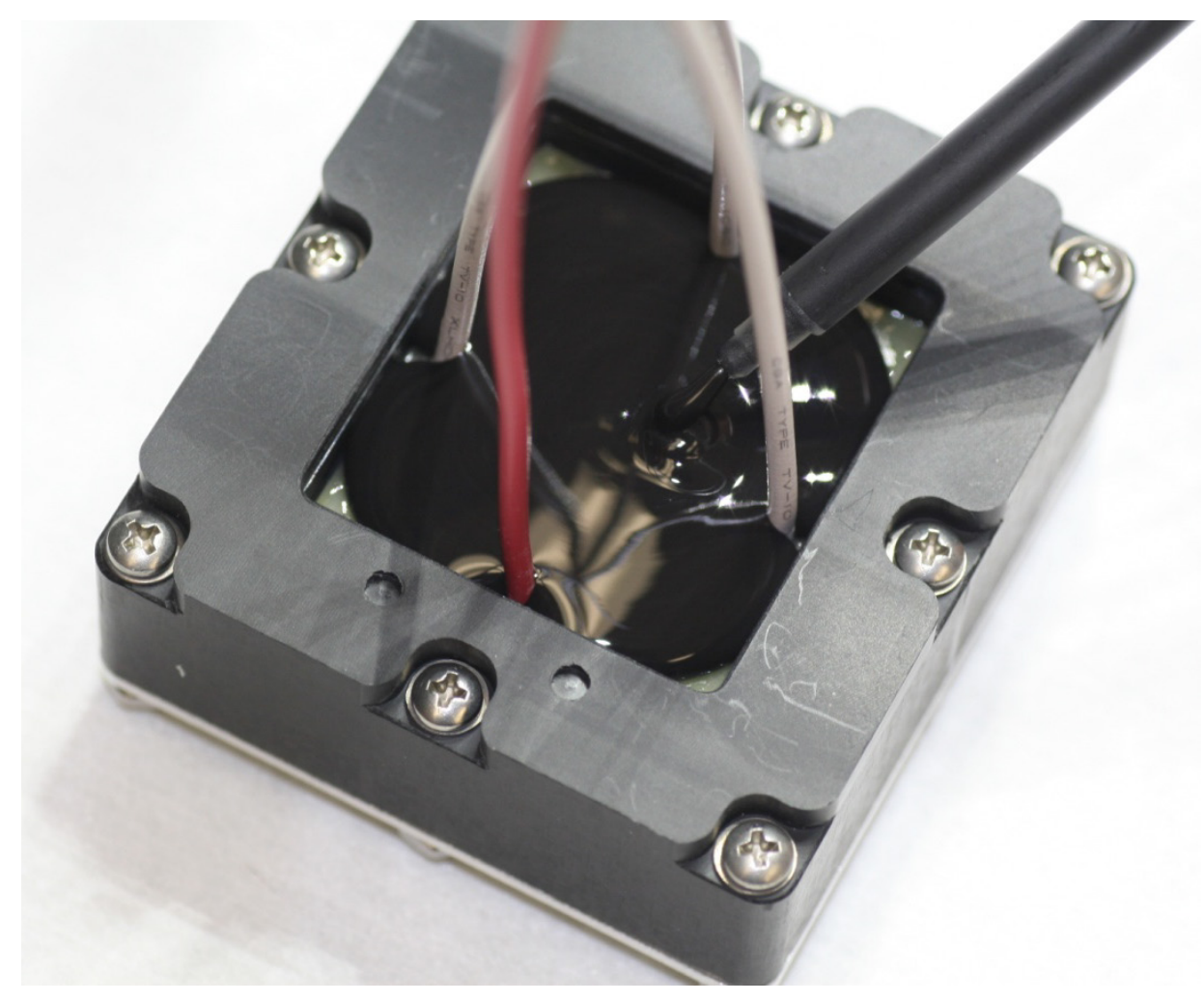

Fig. 13 Photograph depicting fill of case cavity with Cotronics Duralco ${ }^{\circledR} 4525 \mathrm{~N}$

Table 2 presents properties of the various encapsulants and adhesives used for fabricating the Version 3 module. Figure 14 is a photograph of the completed module.

Table 2 Version 3 module encapsulants \& adhesives

\begin{tabular}{|c|c|c|c|c|c|c|}
\hline Material & $\begin{array}{l}\text { Maximum } \\
\text { temp. } \\
\left({ }^{\circ} \mathrm{C}\right)\end{array}$ & Hardness & Appearance & Cure & Purpose & $\begin{array}{l}\text { Dielectric } \\
\text { strength } \\
\text { (Volts/mil) }\end{array}$ \\
\hline $\begin{array}{c}\text { Dow Corning } \\
\text { Sylgard }{ }^{\circledR} 527 \\
\text { A\&B }\end{array}$ & 150 & $\begin{array}{c}\text { Silicone gel } \\
\text { (soft) }\end{array}$ & Clear & $\begin{array}{l}\text { Room } \\
\text { temp }\end{array}$ & Die cavity & 425 \\
\hline $\begin{array}{c}\text { Cotronics } \\
\text { Duralco }^{\circledR} \\
4525 \mathrm{~N}\end{array}$ & 200 & $\begin{array}{l}\text { Epoxy } \\
\text { (hard) }\end{array}$ & Black & $\begin{array}{l}\text { Room } \\
\text { temp }\end{array}$ & $\begin{array}{l}\text { Bind } \\
\text { terminals } \\
\text { (wires) }\end{array}$ & 450 \\
\hline $\begin{array}{c}\text { Dow } \\
\text { Corning }^{\circledR} \\
3140 \text { RTV }\end{array}$ & 200 & Hard & Clear & $\begin{array}{l}\text { Room } \\
\text { temp }\end{array}$ & $\begin{array}{l}\text { DBC \& Inner } \\
\text { Lid to Case }\end{array}$ & 385 \\
\hline $\begin{array}{c}\text { Bergquist } \\
\text { Gap Pad }{ }^{\circledR} \\
\text { VO US }\end{array}$ & 200 & Ultra Soft & $\begin{array}{c}\text { Mauve/ } \\
\text { Pink }\end{array}$ & $\mathrm{N} / \mathrm{A}$ & $\begin{array}{l}\mathrm{DBC} \text { to } \mathrm{Al} \\
\text { baseplate }\end{array}$ & -- \\
\hline
\end{tabular}




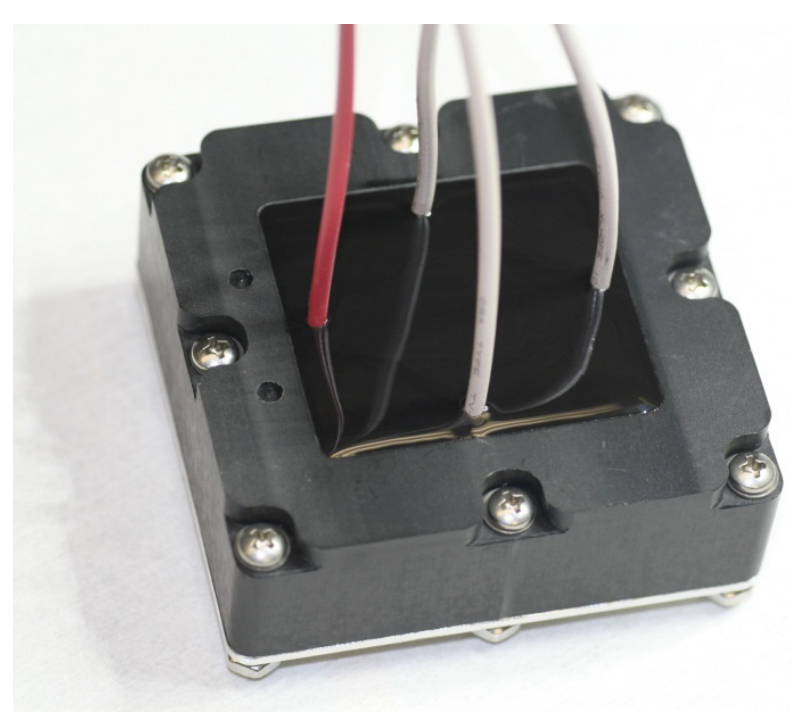

Fig. 14 Completed Version 3, $15 \mathrm{kV}$ full-bridge rectifier module with aluminum baseplate

\section{Conclusions}

The advent of $\mathrm{SiC}$ devices capable of operating well beyond the voltage regimes of COTS packages has given rise to the need for the development of custom modules for ultra-high voltage operation. Three versions of a high-voltage bridge rectifier module have been developed and fabricated at ARL for pulsed-power applications. Version 2 improved upon Version 1, with the copper baseplate being replaced with a low-CTE CarbAl ${ }^{\mathrm{TM}}$ baseplate material, doing away with the issue of crack formation in the ceramic during soldering. The availability of the thicker ceramic layer served to eliminate the requirement of the dielectric pocket for Version 3. 


\section{List of Symbols, Abbreviations, and Acronyms}
AlN aluminum nitride
COTS commercial off-the-shelf
CTE coefficient of thermal expansion
DBC direct bonded copper
ENIG electroless nickel immersion gold
H.V. high voltage
IPA isopropyl alcohol
JBS junction-barrier Schottky
RTV room temperature vulcanization
$\mathrm{SiC} \quad$ silicon carbide 


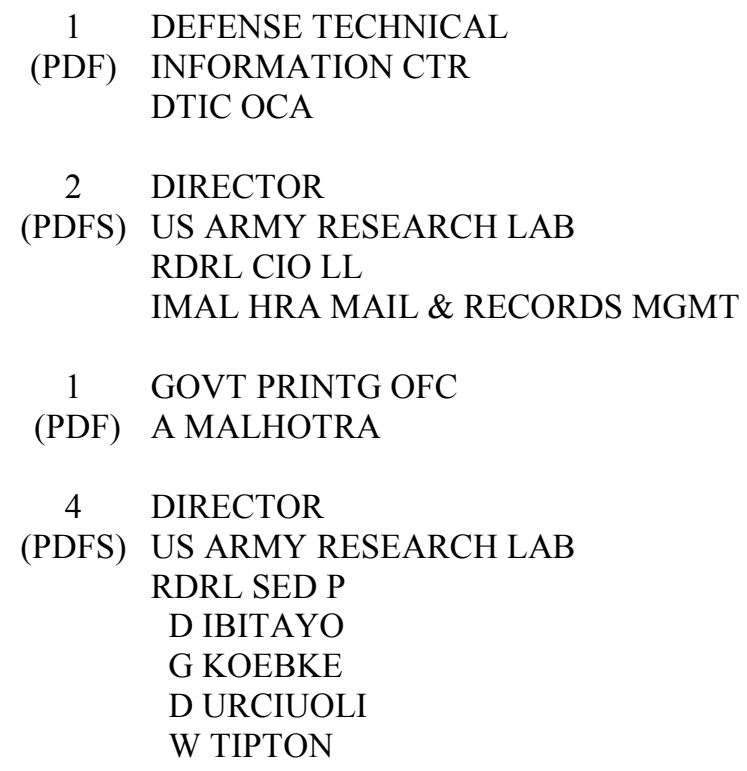

